\title{
Extracellular signal-regulated kinase (ERK) in glucose-induced and endothelin-mediated fibronectin synthesis
}

\author{
Xiping Xin ${ }^{1}$, Zia A Khan ${ }^{1}$, Shali Chen ${ }^{1}$ and Subrata Chakrabarti ${ }^{1,2}$ \\ ${ }^{1}$ Department of Pathology and ${ }^{2}$ Department of Microbiology and Immunology, University of Western Ontario, \\ London, Ontario, Canada
}

\begin{abstract}
Increased extracellular matrix protein deposition and basement membrane thickening are important features of diabetic angiopathy. One key matrix protein that has been shown to be instrumental in basement membrane thickening is fibronectin (FN). We have previously demonstrated that glucose-induced increased expression of endothelin-1 (ET-1), may in part, be responsible for increased FN expression via nuclear factor- $\kappa$ B (NF- $\kappa$ B) and activating protein (AP-1) activation. The present study was aimed at elucidating the mechanism of ET-1 with respect to mitogen-activated protein kinase/extracellular signal-regulated kinase (MAPK/ERK) pathway activation and glucose-induced FN upregulation. Human endothelial cells were exposed to either low (5 mM) or high (25 mM) glucose levels. Cells in low glucose were also treated with ET-1 peptide (5 nM). In addition, we treated cells exposed to high glucose levels with specific MAPK/ERK inhibitor PD098059 (50 $\mu$ M), dual ETreceptor antagonist, bosentan $(10 \mu \mathrm{M})$, and PKC blocker, chelerythrine (1 $\mu \mathrm{M})$. Following incubation period, RNA and total proteins were extracted for RT-PCR for FN and immunoblot analysis of MAPK/ERK activation. Confocal microscopy was performed for analysis of FN protein and nuclear localization of activated Elk. Electrophoretic mobility shift assay was carried out to detect NF- $\kappa$ B and AP-1 activation. Our data demonstrates that high glucose-induced upregulation of FN messenger RNA and protein levels occur via activation of MAPKJ ERK pathway, which was prevented by treatment of cells with bosentan, PD098059 and PKC blocker chelerythrine. Confocal microscopy demonstrated nuclear localization of phospho-Elk protein. Glucoseinduced FN expression was also associated with protein kinase C, NF- $\kappa$ B, and AP-1 activation. These results suggested that glucose-induced, ET- and PKC-dependent, upregulation of FN is, in part, mediated via MAPKI ERK activation.
\end{abstract}

Laboratory Investigation (2004) 84, 1451-1459, advance online publication, 27 September 2004; doi:10.1038/labinvest.3700178

Keywords: glucose; endothelin-1; MAP kinase (ERK1/2); gene expression; fibronectin; protein kinase C

Imbalance between extracellular matrix (ECM) protein production and degradation is an important feature of chronic diabetic complications. ${ }^{1,2}$ Such imbalance is integral to a key structural anomaly of the vascular tissue in diabetes, basement membrane thickening. One predominant ECM protein that has been shown to be upregulated in diabetic angiopathy is fibronectin (FN). ${ }^{3-6} \mathrm{FN}$ is a glycoprotein of $250 \mathrm{kDa}$, which in addition to being one of the most abundant proteins in the ECM, is also one of the most specialized. ${ }^{7}$ FN molecules interact with various matrix proteins and also modulate numerous cellular processes by interacting with cell surface receptors. ${ }^{7}$ In vitro studies have demon-

Correspondence: Professor S Chakrabarti, PhD, Department of Pathology, 4011 Dental Sciences Building, University of Western Ontario, London, Ontario, Canada.

E-mail: schakrab@uwo.ca

Received 31 March 2004; revised 20 July 2004; accepted 27 July 2004; published online 27 September 2004 strated upregulation of FN by high glucose levels in both vascular endothelial cells and mesangial cells. ${ }^{6,8}$

Elaboration of various hyperglycemia-induced vasoactive factors and growth factors is implicated in augmented FN expression. ${ }^{1,2}$ Mechanisms of increased ECM protein production may also include activation of mitogen-activated protein kinase (MAPK) pathway. ${ }^{8}$ MAP kinase family form a group of serine/threonine kinases that are activated via phosphorylation following stimulation. ${ }^{9}$ MAPK family includes extracellular signal-regulation kinase (ERK), c-jun-N-terminal kinase (JNK) and p38 kinase. ERK is one of the best characterized MAPK families. Generally accepted as a proliferation and differentiation MAPK, ERK is activated by many biological and physiochemical stimuli including growth factors, vasoactive factors, and osmotic stresses. ${ }^{9}$ Activation of ERK follows a typical threestage phosphorylation process. ${ }^{10}$ Following stimula- 
tion, activated Raf (MAPKKK) phosphorylates MEK1/2 (MAPKK), which subsequently phosphorylates ERK1/2 (MAPK). There are numerous downstream molecules that are activated by phosphorylated ERK1/2 including nuclear factor Elk. ${ }^{11}$

Glucose-induced coactivation of MAPK and protein kinase $\mathrm{C}$ (PKC) has been demonstrated in the mesangial cells. ${ }^{12}$ Furthermore, both PKC-dependent and -independent MAPK activation has been shown in the kidney. ${ }^{13}$ Downstream effect of MAPK activation may also cause activation of transcription factors such as nuclear factor-kappa B (NF- $\kappa$ B) and activating protein-1 (AP-1). ${ }^{14}$ We have previously demonstrated that glucose-induced upregulation of FN in endothelial cells is, in part, mediated by endothelin-1 (ET-1) expression and NF- $\kappa$ B and AP-1 activation. $^{6}$ In other systems, MAPK pathwaymediated regulation of NF- $\kappa$ B and AP-1 activation has also been demonstrated. ${ }^{15,16}$

In order to gain insight into the mechanistic basis of glucose-induced FN expression, we have evaluated the potential role of MAPK/ERK activation in glucose-induced and ET-1-mediated FN expression. In addition, we have studied a possible crosstalk between MAPK/ERK and PKC, and its relationship to $\mathrm{NF}-\kappa \mathrm{B}$ and $\mathrm{AP}-1$ activation.

\section{Materials and methods}

\section{Endothelial Cells}

Human umbilical vein endothelial cells (American Type Culture Collection, Rockville, MD, USA) were cultured as previously described. ${ }^{6}$ Subconfluent cells were incubated with either $5 \mathrm{mM}$ D-glucose (control) or $25 \mathrm{mM}$ D-glucose (high glucose; HG). Cells in $5 \mathrm{mM}$ glucose were also treated with $5 \mathrm{nM}$ ET-1 (Peninsula Laboratories, Belmont, CA, USA). In addition, we incubated cells exposed to high and low glucose levels with either $10 \mu \mathrm{M}$ dual ET receptor antagonist, bosentan (Courtesy of Dr M Clozel/Acetelion Ltd, Allschwill, Switzerland), $50 \mu \mathrm{M}$ specific MEK1/2 inhibitor PD098059 (New England Biolabs, Inc., Beverly, MA, USA), and $10 \mu \mathrm{M}$ U0126 (Promega Corporation, Pittsburgh, PA, USA) or $1 \mu \mathrm{M}$ PKC inhibitor, chelerythrine (Sigma-Aldrich, Ontario, Canada).
Cells were pretreated with inhibitors for $1 \mathrm{~h}$ before exposure to high glucose. Concentrations of peptides and inhibitors were in accordance with the manufacturer's recommendations. Following 24-h incubation period, RNA was extracted for FN gene expression analysis by real-time RT-PCR. In addition, total and nuclear proteins were isolated for analysis of MAPK pathway activation and transcription factor activation, respectively. In addition, cells were cultured on coverslips for immunofluorescent analysis and confocal microscopy.

\section{Cell Viability Assay}

We used crystal violet assay to measure cell viability and to exclude potential cytotoxic effects of the compounds as described previously with some minor modification. ${ }^{17}$ HUVECs were seeded at $2 \times 10^{4}$ cells/well in 96-well microtiter plates. When the cells were confluent, they were treated with various concentrations of PD98059, U0126, bosentan, chelerythrine for $24 \mathrm{~h}$ after they underwent $12 \mathrm{~h}$ serum-free conditions. Cells were washed with PBS buffer, fixed with methanol for $5 \mathrm{~min}$, and then stained for $10 \mathrm{~min}$ with a $0.1 \%$ crystal violet solution. Following three washes, the dye was eluted with $0.1 \mathrm{M}$ trisodium citrate in $50 \%$ ethanol for $10 \mathrm{~min}$. Optical density at $630 \mathrm{~nm}$ was monitored on a microtiter plate reader.

\section{RNA Isolation and Complementary DNA Synthesis}

Real-time quantitative RT-PCR for FN gene expression was carried out in LightCycler ${ }^{\mathrm{TM}}$ (Roche Diagnostics Canada, Quebec, Canada) using SYBR Green 1 for detection. PCR reactions were performed essentially as described. ${ }^{18}$ The reaction mixture consisted of $10 \mu \mathrm{l}$ of ReadyMix SYBR ${ }^{\mathrm{TM}}$ (SigmaAldrich, Canada), $1.6 \mu \mathrm{l}$ of $25 \mathrm{mM} \mathrm{MgCl}_{2}, 1 \mu \mathrm{l}$ of each forward and reverse $10 \mu \mathrm{M}$ primers (Table 1), $5.4 \mu \mathrm{l} \mathrm{H}_{2} \mathrm{O}$, and $1 \mu \mathrm{l}$ complementary DNA (cDNA) template. Messenger RNA (mRNA) levels were quantified using the standard curve method. Standard curves were constructed by using serially diluted standard template. The data were normal-

Table 1 Oligonucleotide sequences for real-time RT-PCR

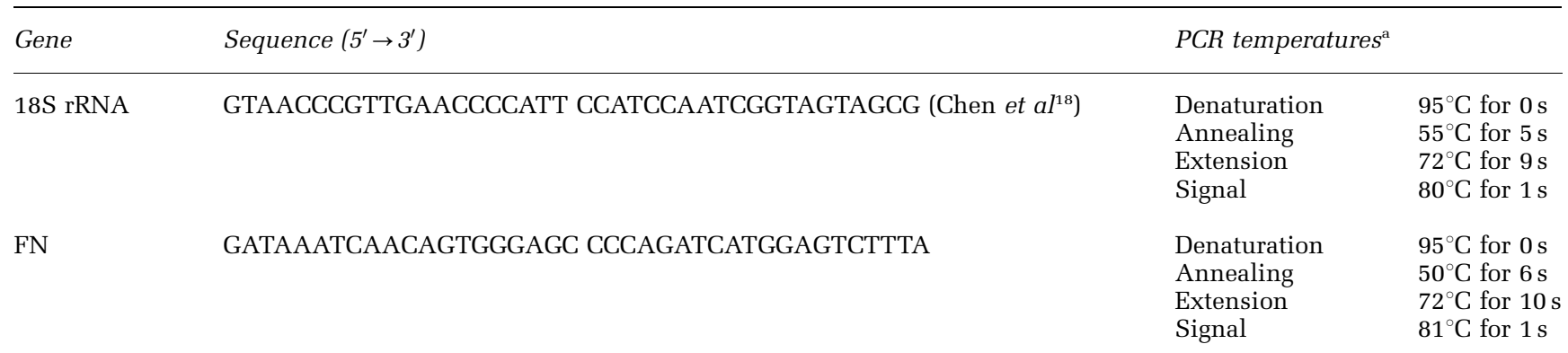

\footnotetext{
${ }^{\mathrm{a}}$ Initial denaturation was carried out at $95^{\circ} \mathrm{C}$ for $1 \mathrm{~min}$. Ramp rate for all PCR phases was $20^{\circ} \mathrm{C} / \mathrm{s}$.
} 
ized to $18 \mathrm{~S}$ ribosomal RNA (rRNA) ${ }^{19}$ to account for differences in reverse transcription efficiencies.

\section{Immunofluorescent Microscopy}

Endothelial cells were cultured in 12-well plates (Fisher Scientific, Ontario) with coverslips. Subconfluent cells were treated with various stimulators and inhibitors for $24 \mathrm{~h}$ as mentioned above. Following treatment, cells were fixed in anhydrous ethanol and probed with either polyclonal rabbit antihuman FN antibody (1:1000; Dako Diagnostics Canada Inc., Ontario, Canada) or polyclonal antirabbit Elk antibody (1:100; NEW England BioLabs Ltd, Ontario, Canada). FITC labeled goat anti-rabbit secondary antibody (Vector Laboratories, Ontario, Canada) was used for detection using a confocal microscope equipped with UV and FITC/TRITC filters (Zeiss LSM 410; Carl Zeiss Canada Ltd, Ontario, Canada).

\section{Protein Purification and Western Blot Analysis}

Total proteins from endothelial cells were isolated by homogenizing cells in complete RIPA buffer ( NaCl $0.877 \mathrm{~g}$, deoxycholate $1 \mathrm{~g}, 1 \mathrm{M}$ Tris-HCl $\mathrm{pH}$ $7.55 \mathrm{ml}$, and $10 \%$ sodium dodecyl sulfate $1 \mathrm{ml}$; volume adjusted to $100 \mathrm{ml}$ using $\mathrm{ddH}_{2} \mathrm{O}$ ) and protease inhibitor. Total proteins were then quantified by using BCA protein assay $\mathrm{kit}^{\mathrm{TM}}$ (Pierce Endogen, Rockford, IL, USA). MAPK/ ERK pathway activation was assessed by using polyclonal phospho-Raf antibody (1:1000; NEW England BioLabs Ltd, Ontario, Canada), phospho-MEK1/2 antibody (1:1000; NEW England BioLabs Ltd), and phosphop44/42 MAPK antibody (1:1000; NEW England BioLabs Ltd). ECL-PLUS Western blotting detection kit (Amersham Parmacia Biotech., Piscataway, NJ, USA) was used for detection.

\section{Electrophoretic Mobility Shift Assay}

Electrophoretic mobility shift assay (EMSA) was performed as described previously. ${ }^{6}$ Briefly, NF- $\kappa \mathrm{B}$ and AP-1 consensus oligonucleotide DNA probes (Promega, WI, USA) (Table 2) were prepared by end labeling with $\left[\gamma_{-}{ }^{32} \mathrm{P}\right]$ ATP (Amersham, Quebec, Canada) using T4 polynucleotide kinase. The probes

Table 2 Oligonucleotide sequences for EMSA

\begin{tabular}{ll} 
Transcription factor & Oligonucleotide sequence \\
\hline NF- $\kappa \mathrm{B}$ & 5'-AGT TGA GGG GAC TTT CCC AGG C-3' \\
& 3'-TCA ACT CCC CTG AAA GGG TCC G-5' $^{\prime}$ \\
& \\
AP-1 & 5'-CGC TTG ATG AGT CAG CCG GAA-3' \\
& 3'-GCG AAC TAC TCA GTC GGC CTT-5'
\end{tabular}

were purified by ethanol precipitation and resuspended in $10 \mathrm{mM}$ Tris and $1 \mathrm{mM}$ EDTA (pH 7.6). Amount of $5 \mu \mathrm{g}$ of nuclear proteins were incubated with $100000 \mathrm{cpm}$ of ${ }^{32} \mathrm{P}$-labeled consensus oligonucleotides for $30 \mathrm{~min}$ at room temperature. The incubation was carried out in a buffer containing $10 \mathrm{mM}$ Tris (pH 7.5), $50 \mathrm{mM} \mathrm{NaCl}, 1 \mathrm{mM} \mathrm{MgCl}_{2}, 5 \%$ glycerol, $0.05 \%$ IGEPAL CA-630, $0.5 \mathrm{mM}$ EDTA, $0.5 \mathrm{mM}$ DTT, and $0.5 \mu \mathrm{g}$ of poly(dI-dC). ProteinDNA complexes were resolved on a standard $6 \%$ (NF- $\kappa \mathrm{B}$ ) and $4 \%$ (AP-1) nondenaturing polyacrylamide gel in 0.5 Tris-boric acid-EDTA running buffer. After $30 \mathrm{~min}$ of electrophoresis at $350 \mathrm{~V}$, gels were dried under heated vacuum onto Whatman paper and subjected to autoradiography from overnight to 3 days. Anti-NF- $\kappa$ B (p65) monoclonal antibody and anti-AP-1 (c-Jun) polyclonal antibody (Santa Cruz Biotechnology, Santa Cruz, CA, USA) was used for the supershift assay. The specificity of binding was further confirmed by incubation with 100-fold unlabeled oligonucleotides. The blots were quantified by densitometry. ${ }^{6}$

\section{Statistical Analysis}

The data are expressed as mean \pm s.e.m. and were analyzed by ANOVA followed by post hoc analysis. Differences were considered significant at values of $P<0.05$.

\section{Results}

\section{Glucose Causes FN mRNA and Protein Upregulation via ET-1}

Exposure of endothelial cells to high glucose levels and ET-1 peptide upregulated FN mRNA levels as determined by real time RT-PCR $(P<0.05$; Figure 1a). These findings are in accordance with our previous studies, which have shown increased expression of FN by high ambient glucose levels and fibrogenic proteins such as ET- $1 .{ }^{6}$ Incubation of cells exposed to high glucose concentration with dual ET-receptor antagonist, bosentan, abolished glucose-induced FN upregulation $(P<0.05$; Figure 1a). Similar to our previous study, we have demonstrated that a maximal increase of $\mathrm{FN}$ mRNA expression is reached after $24 \mathrm{~h}$ of exposure and the increase was maintained up to $72 \mathrm{~h}$ (data not shown). ${ }^{6}$ Hence in subsequent experiments, $24 \mathrm{~h}$ exposure in high glucose was performed. In order to elucidate whether alterations in FN mRNA levels coincide with alteration in protein levels, we analyzed endothelial cells with respect to $\mathrm{FN}$ protein expression by immunofluorescence microscopy. Our results indicate upregulation of FN protein levels in cells exposed to high glucose concentration (Figure 1b-d). Treatment of cells with ET-1 peptide produced similar results as with exposure to high levels of glucose (data not shown). 
Furthermore, both glucose-induced and basal FN mRNA expression was prevented by dual ET-1 receptor antagonist, bosentan.
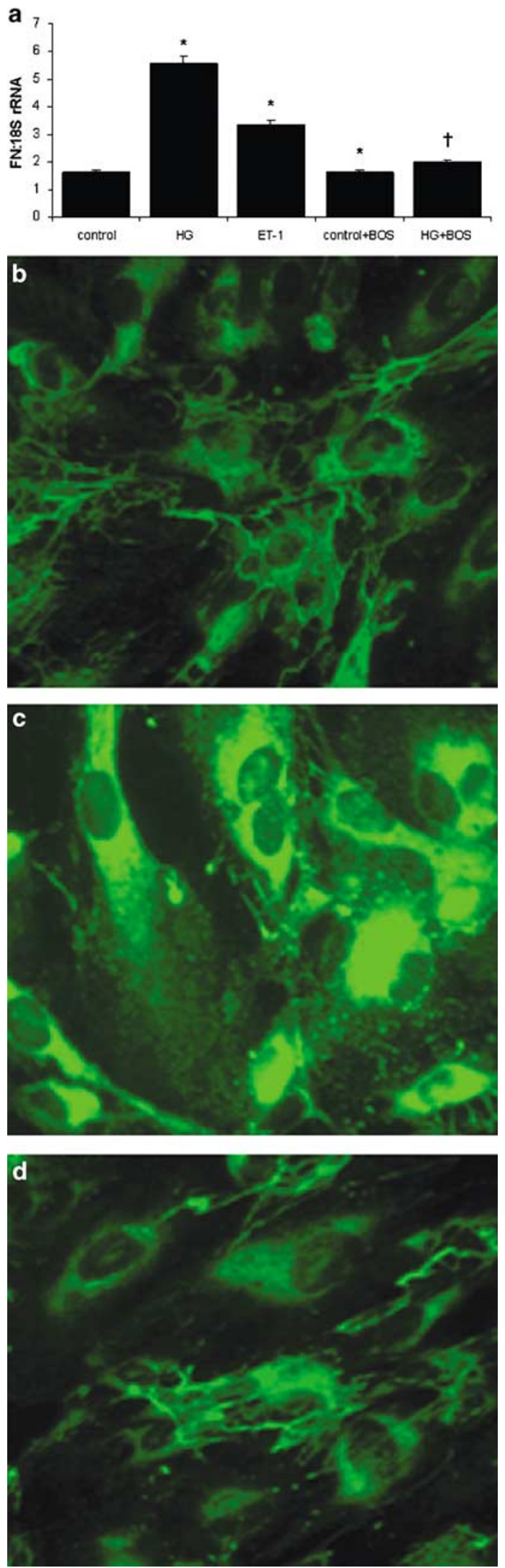

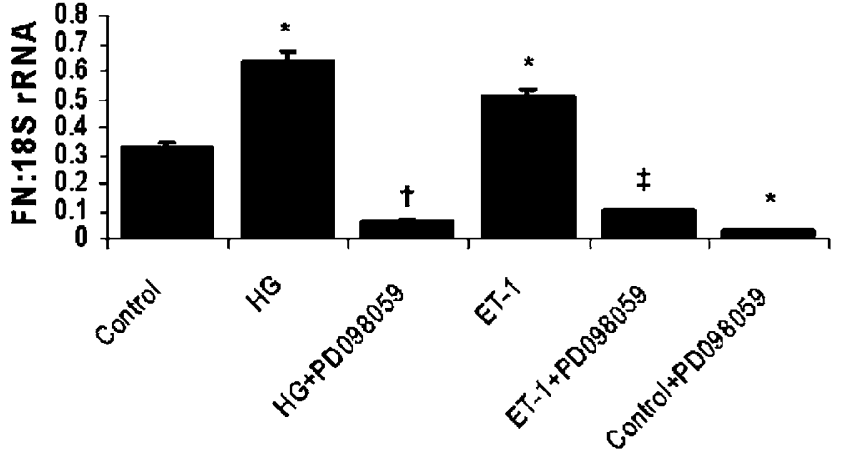

Figure 2 Quantitative FN mRNA expression in endothelial cells by real time RT-PCR showed that both high glucose- and ET-1 peptide-mediated FN expression was normalized by inhibitor of MAPK/ERK pathway, PD098059. (ET-1 $=5 \mathrm{nM}$ ET-1 peptide alone; ET-1 + PD098059 = 5 nM ET-1 peptide + $10 \mu \mathrm{M}$ PD098059; $\mathrm{HG}+\mathrm{PD} 098059=\mathrm{HG}+10 \mu \mathrm{M}$ PD098059; HG $=25 \mathrm{mM}$ glucose, control + PD098059 $=$ control $+10 \mu \mathrm{M}$ PD098059; ${ }^{*} P<0.05$ compared to control; ${ }^{\dagger} P<0.05$ compared to ET-1; ${ }^{\ddagger} P<0.05$ compared to HG; $n=4$ /treatment.)

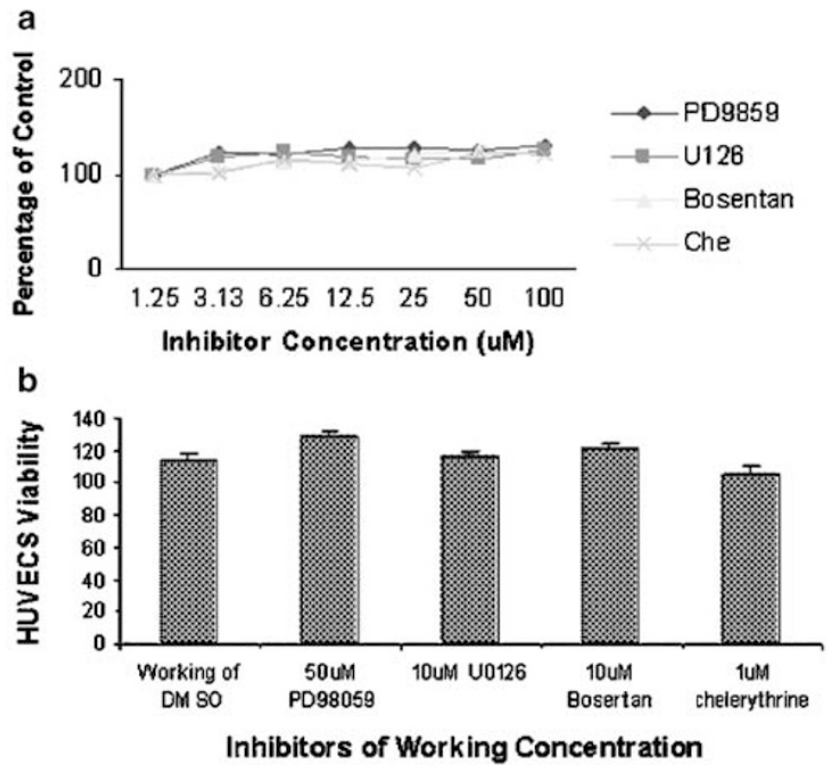

Figure 3 Cell viability analysis (mean \pm s.e.m.) by crystal violet assay: upper panel represents data at various concentrations of different inhibitors used in the experiments, lower panel shows cell viability at the working concentration of the reagents, normalized to DMSO-exposed control. No significant differences were noted.

Figure 1 (a) Quantitative FN mRNA expression in endothelial cells exposed to high glucose levels and ET-1 peptide as determined by real-time RT-PCR showing high glucose-induced upregulation of FN mRNA which was normalized by treatment of cells with dual ET receptor antagonist, bosentan. Treatment of cells to ET-1 peptide also increased FN mRNA levels. Representative micrograph of FN protein immunofluorescent analysis in control (b), high glucose-treated (c), and high glucose with bosentan-treated (d) endothelial cells. $($ ET- $1=5 \mathrm{nM}$ ET-1 peptide alone; $\mathrm{HG}=25 \mathrm{mM}$ glucose, $B o s=\mathrm{HG} / \mathrm{LG}+10 \mu \mathrm{M}$ bosentan; ${ }^{*} P<0.05$ compared to control; ${ }^{\dagger} P<0.05$ compared to HG; $n=4$ / treatment.) 
Glucose-Induced ET-1-Mediated FN Synthesis is Mediated via MAPK Pathway

In order to elucidate whether glucose- and ET-1induced FN upregulation is mediated via activation of MAPK/ERK, we evaluated the role of specific MEK inhibitor in cells exposed to high glucose and ET-1 peptide. PD098059 reduced both basal and glucose-induced FN upregulation (Figure 2). U0126, another specific MAPK/ERK inhibitor, also prevented high glucose-induced FN mRNA expression (data not shown). In order to establish that the changes in gene expression are not secondary to cytotoxicity and cell death, we performed crystal violet assay with all inhibitors at various doses including the concentrations used to measure gene expression. No significant effects were seen on cell viability (Figure 3).

Furthermore, activation of MAPK/ERK pathway by high glucose and ET-1 peptide was detected by immunoblot analysis with specific polyclonal phospho-antibodies. High glucose concentration significantly increased activation of Raf, MEK1/2, and ERK1/2 $(P<0.05$; Figure 4). Similar results were obtained when cells were treated with ET-1 peptide alone. To determine whether glucose-induced activation of MAPK/ERK is mediated via ET-1, we analyzed ERK pathway activation in cells exposed to a

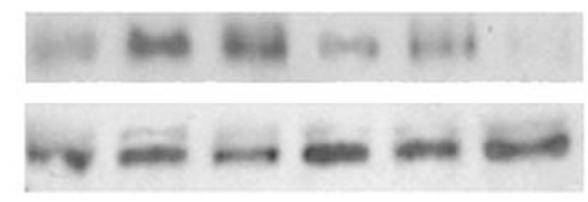

b

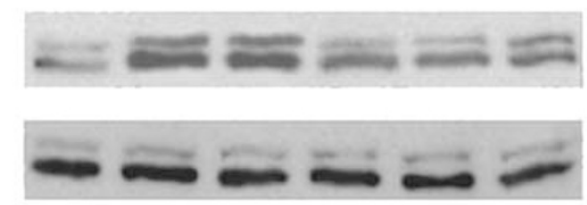

C

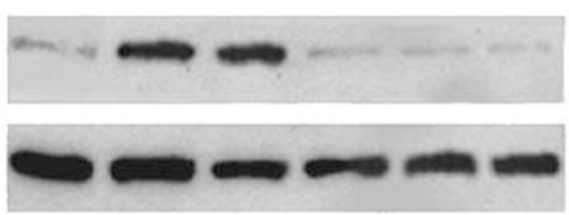

d

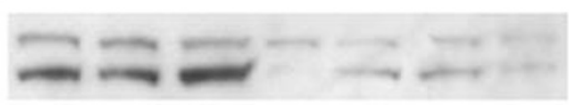

P-ß-raf

$\beta$-raf

P-MEK1/2

$\mathrm{MEK} 1 / 2$

P-ERK1/2

B-Actin

g

P-MEK1/2
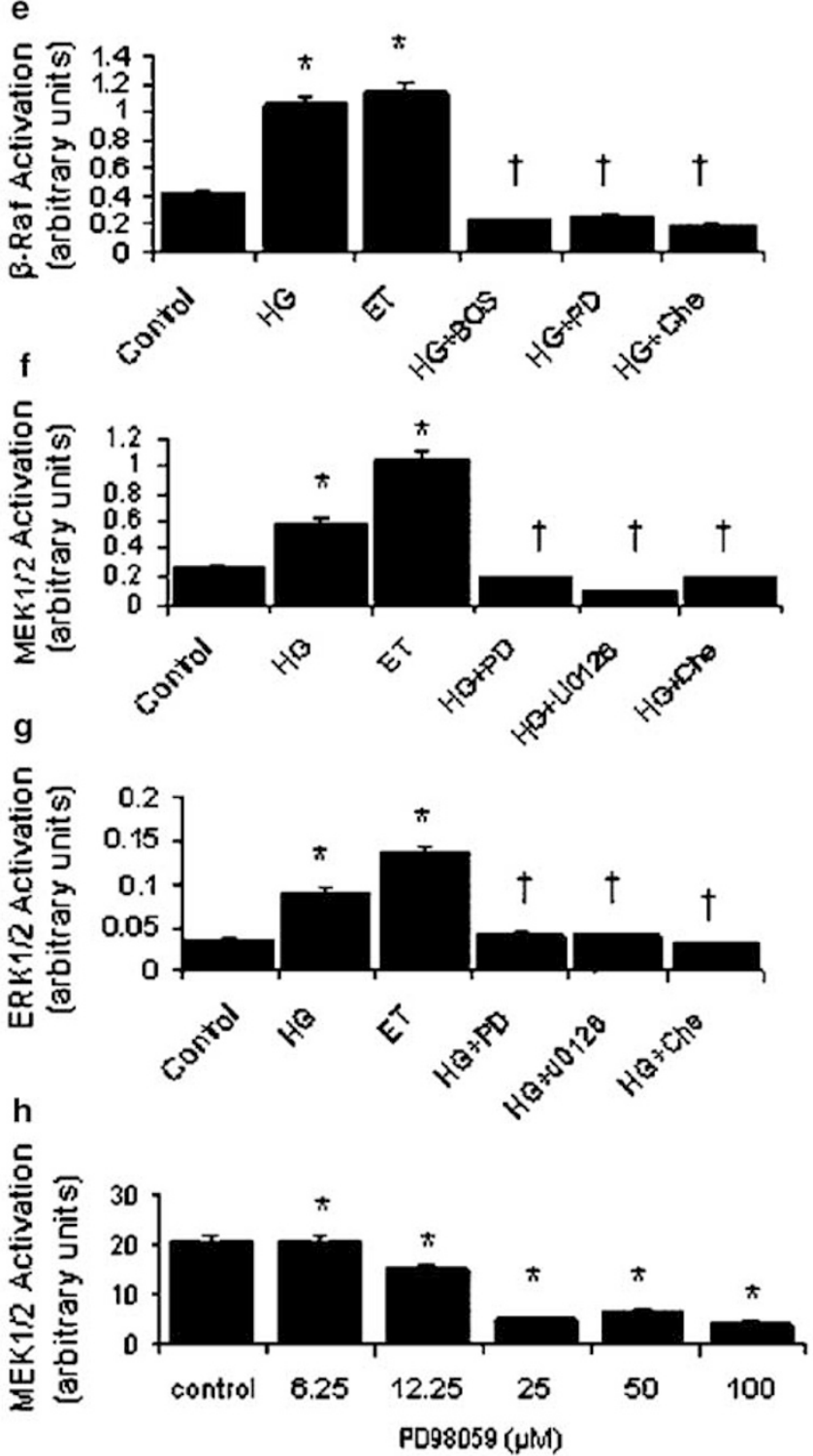

Figure 4 (a-d) Representative immunoblot analysis of MAPK/ERK activation showing: (a) phospho-Raf, (b) phospho-MEK1/2, and (c) phospho-ERK1/2. (d) Phospho-MEK1/2 showing dose-dependent effect of PD098059 (e-h) semi-quantitative analysis of (a-d), (ET$1=5 \mathrm{nM}$ ET-1 peptide alone; $\mathrm{HG}=25 \mathrm{mM}$ glucose, $\mathrm{HG}+\mathrm{Bos}=\mathrm{HG}+10 \mu \mathrm{M}$ bosentan; HG $+\mathrm{PD} 098059=\mathrm{HG}+10 \mu \mathrm{M}$ PD098059; che $=$ HG + chelerythrene $1 \mu \mathrm{M}$, ${ }^{*} P<0.05$ compared to control; ${ }^{*} P<0.05$ compared to HG; panels $\mathbf{d}$ and $\mathbf{h}$ show dose-dependent effect of PD098059, $n=4$ /treatment.) MAPK activation was blocked by MAPK blocker, PKC blocker as well as ET-blocker. 
1456

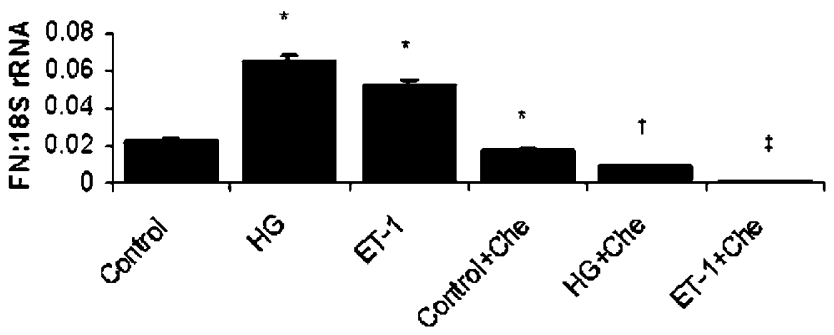

Figure 5 Quantitative mRNA analysis showing interaction between glucose-induced PKC and MAPK/ERK pathway activation in mediating FN mRNA upregulation in endothelial cells. Both high glucose- and ET-1-induced FN mRNA expression was blocked by PKC inhibitor, chelerythrine. ( $\mathrm{HG}=25 \mathrm{mM}$ glucose; ET- $1=5 \mathrm{nM}$ ET-1 peptide alone; control + Che $=$ control $+1 \mu \mathrm{M}$ chelerythrine $\mathrm{HG}+\mathrm{Che}=\mathrm{HG}+1 \mu \mathrm{M}$ chelerythrine; $\mathrm{ET}-1+\mathrm{Che}=$ $5 \mathrm{nM}$ ET-1 peptide $+1 \mu \mathrm{M}$ chelerythrine; ${ }^{*} P<0.05$ compared to control; ${ }^{\dagger} P<0.05$ compared to HG; ${ }^{\ddagger} P<0.05$ compared to ET-1; $n=4 /$ treatment.) high glucose and dual ET-receptor antagonist. Inhibition of ET receptor signaling in cells exposed to high glucose completely prevented activation of Raf, MEK1/2, and ERK1/2 $(P<0.05$; Figure 4). PKC activation has been demonstrated to be an important factor in glucose-induced signal transduction. In addition, a possible crosstalk between PKC and MAPK pathways has been demonstrated in mesangial cells. ${ }^{12}$ We found that chelerythrine, a PKC inhibitor, prevented both glucose- and ET-1-induced FN expression (Figure 5). Furthermore, glucoseinduced MEK1/2 activation was prevented by chelerythrine, suggesting PKC activation may modulate glucose-induced MAPK phosphorylation (Figure 4).

To further characterize MAPK activation, we have determined localization of Elk, a downstream effector molecule of MAPK/ERK pathway. Confocal microscopy revealed increased nuclear staining of phosphorylated-Elk in cells exposed to ET-1 peptide
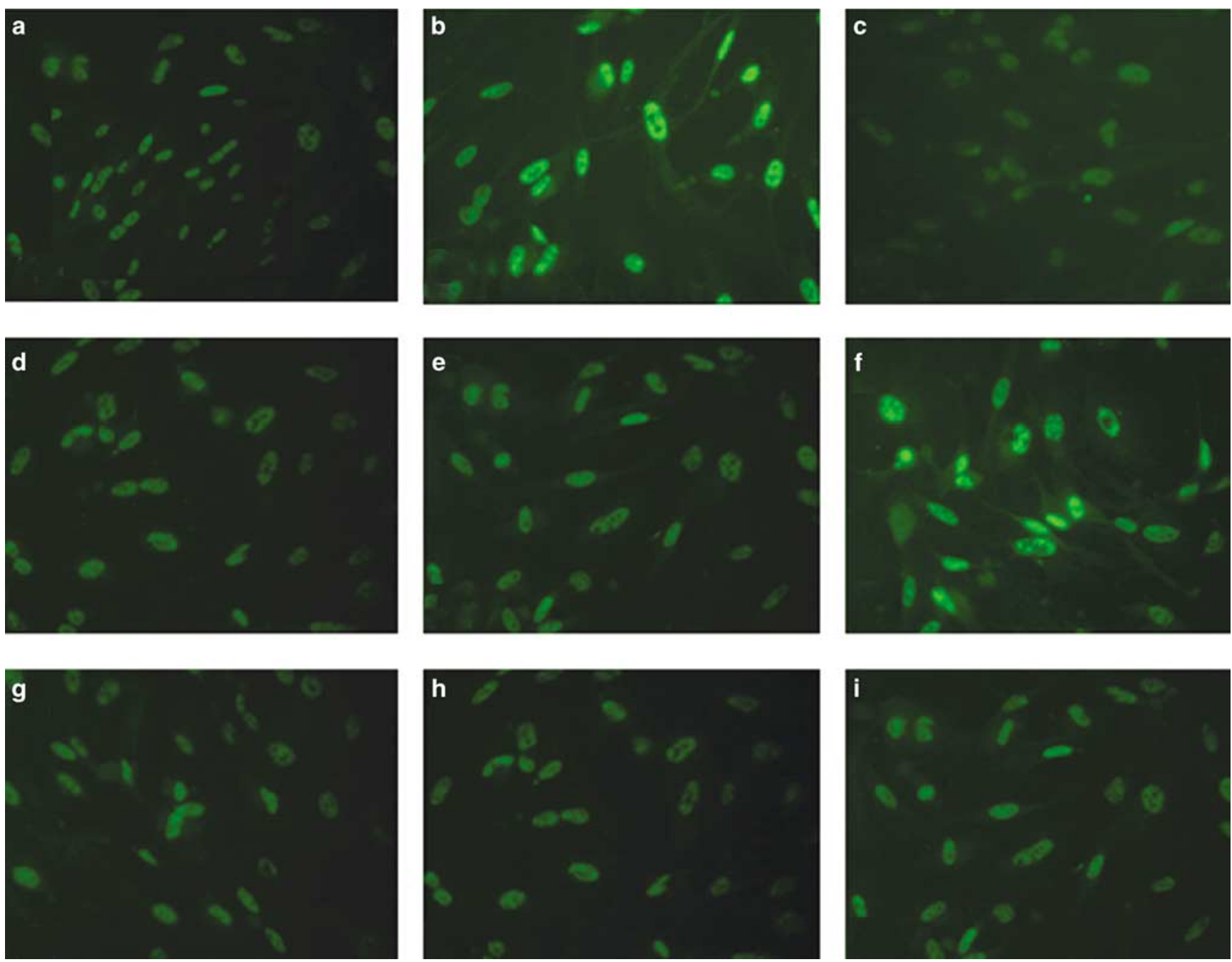

Figure 6 Immunofluorescent analysis of Elk in control endothelial cells (a) and cells exposed to (b) HG, (c) HG + Bosentan, (d) HG + PD098059, (e) HG + Che, (f) ET-1 peptide, (g) ET-1 peptide + PD 098059, and (h) ET-1 + Che. Both glucose and ET-1 increased immunoreactivity of phospho-Elk, which was attenuated by bosentan, MAPK inhibitor, and PKC inhibitor. 
alone or high glucose levels as compared to untreated cells (Figure 6). In addition, inhibitors that prevented glucose-induced FN upregulation and MAPK/ERK activation also reduced nuclear localization of activated Elk (Figure 6).

\section{Transcription Factor Involvement in MAPK-Mediated Signaling of FN Expression}

Our next objective was to determine whether glucose-induced and ET-1-mediated MAPK/ERK pathway activation involves transcription factors, $\mathrm{NF}-\kappa \mathrm{B}$ and AP-1. We performed EMSA in the cells exposed to various conditions as described above. We have previously demonstrated that both NF- $\kappa$ B and AP-1 may be of importance in this scenario. ${ }^{6,18}$ EMSA showed glucose-induced activation of both NF- $\kappa$ B and AP-1 in endothelial cells (Figure 7). Inhibition of MAPK pathway
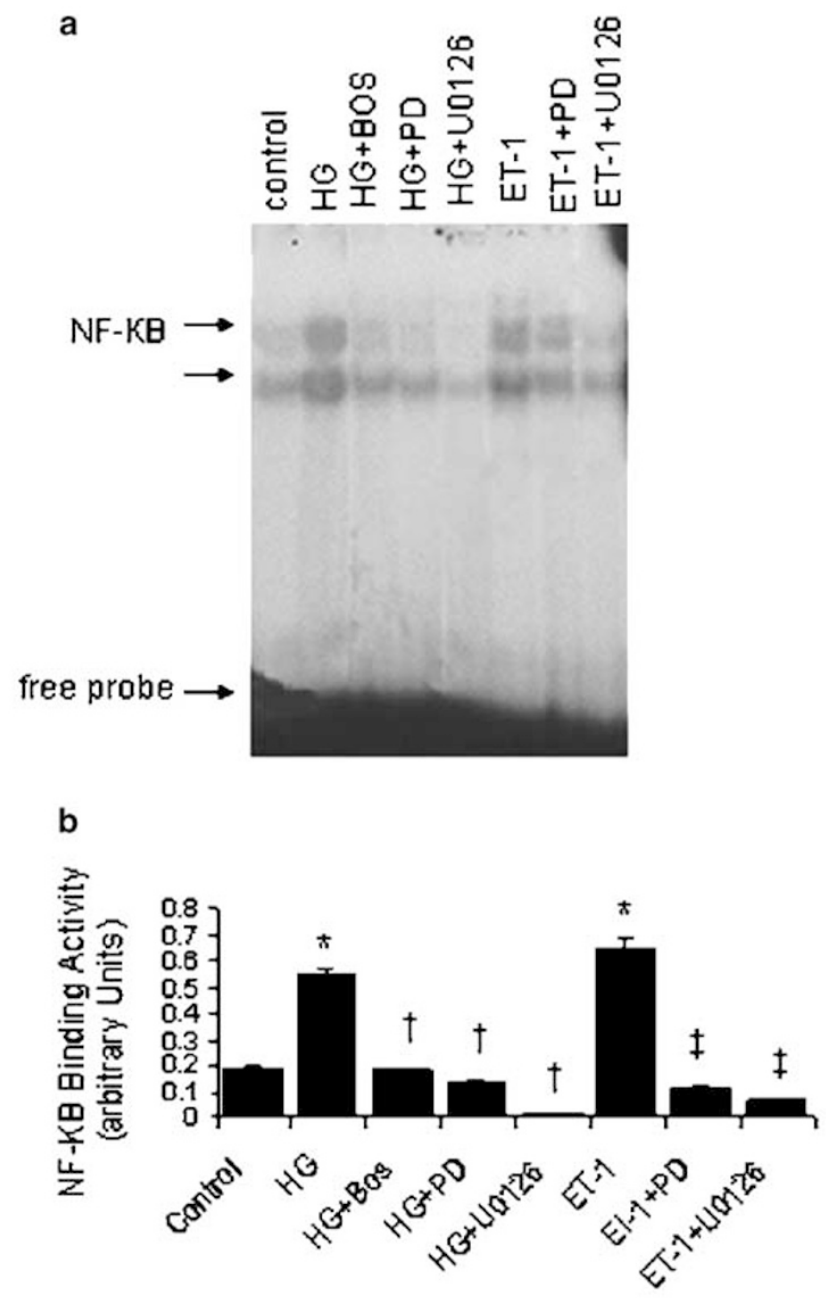

caused marked attenuation of both $\mathrm{NF}-\kappa \mathrm{B}$ and AP-1 activation (Figure 7). These findings suggest that both transcription factors, NF- $\kappa \mathrm{B}$ and AP-1, are predominantly involved in this pathway. Similar activation pattern of transcription factors were also obtained in cells exposed to ET-1 peptide. Dual ET receptor antagonist prevented both NF- $\kappa \mathrm{B}$ and AP-1 activation (Figure 7).

\section{Discussion}

We have evaluated the role of glucose-induced MAPK/ERK pathway activation in FN expression in endothelial cells exposed to high glucose levels. Our key findings indicate that glucose-induced and ET-1-mediated FN upregulation may involve activation of ERK1/2 pathway. We have also demonstrated
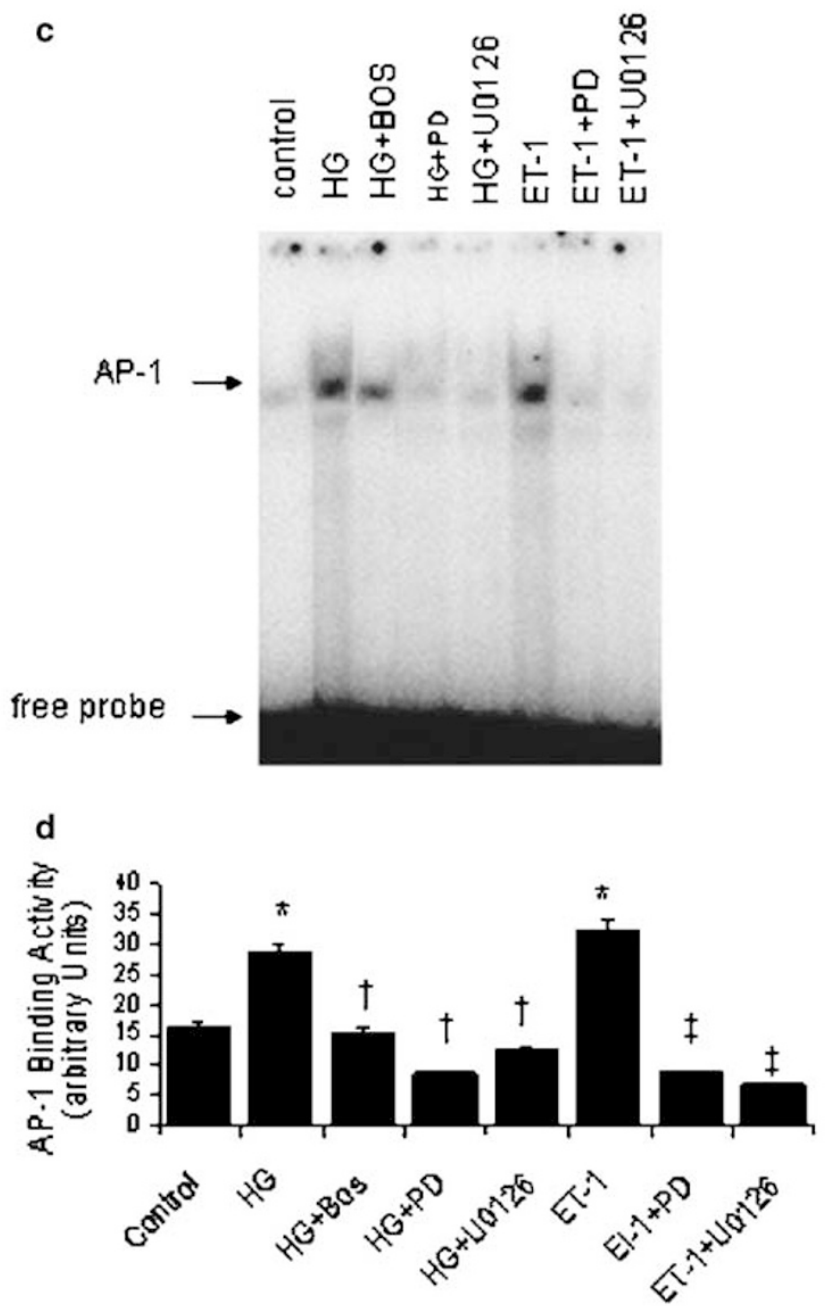

Figure 7 Interaction between high glucose-induced MAPK/ERK activation and activation of transcription factors, NF- $\kappa$ B and AP-1. (a) Representative EMSA showing high glucose- and ET-1-mediated activation of NF- $\kappa$ B. (b) Semiquantitative analysis of NF- $\kappa$ B activation in nuclear extracts from HUVECs as assessed by densitometry. (c) Representative EMSA showing AP-1 activation in HUVECs exposed to high glucose and ET-1 peptide. (d) Semiquantitative analysis of AP-1 activation as determined by densitometry. (Lanes: 1, cold; 2 , control; 3, HG; 4, HG + $10 \mu \mathrm{M}$ Bos; 5, HG + $10 \mu \mathrm{M}$ PD098059; 6, HG + $10 \mu \mathrm{M}$ U02126; 7, $5 \mathrm{nM}$ ET-1; 8, 5 nM ET-1 + $10 \mu \mathrm{M}$ PD098059; and 9, $5 \mathrm{nM}$ ET-1 $+10 \mu \mathrm{M}$ U02126; ${ }^{*} P<0.05$ compared to control; ${ }^{\dagger} P<0.05$ compared to HG; ${ }^{\ddagger} P<0.05$ compared to ET-1; $n=4 /$ treatment.) 
that MAPK/ERK pathway may crosstalk with PKC and predominately mediates signal for FN upregulation via $\mathrm{NF}-\kappa \mathrm{B}$ and $\mathrm{AP}-1$ activation.

Increased expression of ECM proteins such as collagen and FN, leading to basement membrane thickening is the most common pathological feature of chronic diabetic complications. ${ }^{1-5,18}$ We have previously demonstrated an important role of hyperglycemia-induced ET-1 expression in increased ECM protein deposition. ${ }^{4,15,18}$ We have also shown that hyperhexosemia-induced increased FN mRNA expression can be prevented by bosentan treatment in retinas and kidneys of both diabetic and galactose-fed rats. ${ }^{4,15}$ Bosentan treatment also prevented retinal capillary and glomerular basement membrane thickening in these animals. Furthermore, a similar normalization of FN expression by bosentan has been shown in heart tissues of diabetic animals. ${ }^{20}$

The molecular mechanism by which high glucoseinduced ET-1 expression leads to increased FN expression and ECM protein deposition remains to be fully elucidated. However, current studies may suggest that both PKC and phosphatidylinositol 3kinase pathways may converge on MAPKs. ${ }^{21,22}$ Furthermore, biochemical anomalies implicated in hyperglycemia-induced vascular dysfunction such as, nonenzymatic glycation, oxidative stress, and alteration in growth factor and vasoactive factor expression are all involved in alteration of ETs and increased ECM deposition. ${ }^{1,2,23,24}$ It is being increasingly realized that all of these hyperglycemiainduced secondary factors share the capacity to activate MAPKs. These studies suggest that MAPK activation may represent a common signal transduction of glucose-induced ET-1 mediated ECM protein synthesis. It is interesting to note that, the inhibitors used in this study reduced glucose-induced fibronectin (FN) expression below the level expressed by cells in normal glucose. These are not due to cytotoxicity as demonstrated by crystal violet assay. Furthermore, incubation of cells in normal glucose with the inhibitors shows reduction of basal FN expression. In culture, the endothelial cells normally produce fibronectin. Hence, it is conceptually possible that these pathways may also influence basal FN expression. However, identification of exact mechanisms requires further investigation.

Our data demonstrated several important findings; it appears that PKC is an upstream mediator in this pathway as PKC inhibitor blocked MAPK activation. PKC is a known upregulator of ET-1. ${ }^{25}$ On the other hand, ET-1 receptor, being $G_{\mathrm{q}}$ coupled, may activate phospholipase $\mathrm{C}$, increase intracellular calcium and may cause PKC activation. ${ }^{1,2,26}$ Hyperglycemia-induced NF- $\kappa$ B activation may also cause upregulation of ET-1. ${ }^{27}$ In several systems, ET-1 has been also shown to mediate its effect via MAPK pathway. ${ }^{28-30}$ FN gene has both NF- $\kappa$ B and AP-1 binding site on its promoter and may be positively

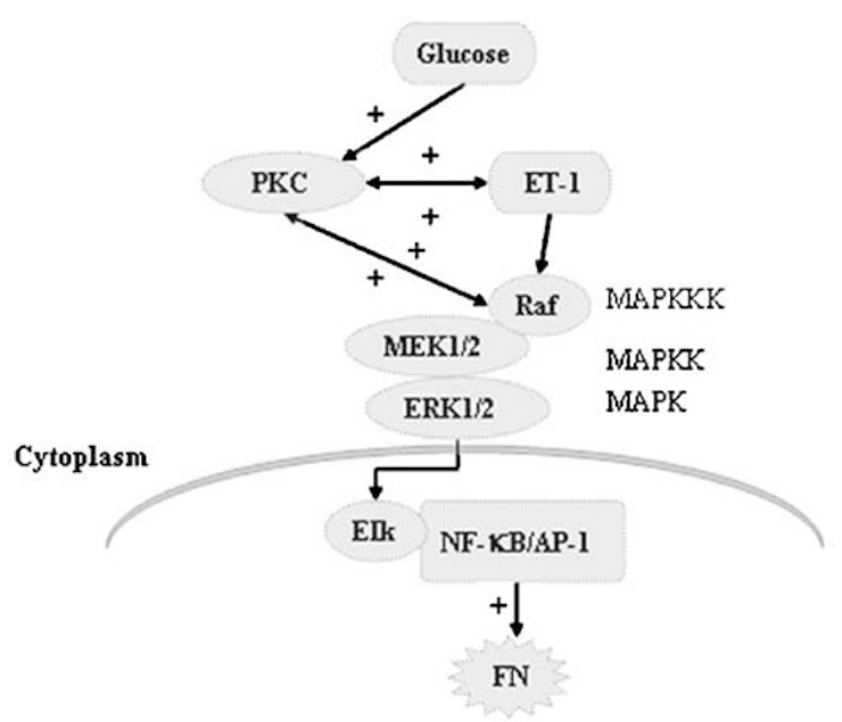

Figure 8 A schematic outline of mechanisms leading to glucoseinduced increased fibronectin synthesis in the endothelial cells as demonstrated in this study.

regulated by both transcription factors. ${ }^{31-35}$ Data from our present study would suggest that MAPK pathway may upregulate FN via NF- $\kappa \mathrm{B}$ and AP-1. However, it is possible that glucose-induced PKC and ET-1 activation may also lead to FN upregulation independent of MAPK activation. A schematic outline of pathways of glucose-induced FN synthesis, as investigated in this study, is outlined in Figure 8.

In summary, we have demonstrated that glucoseinduced PKC and ET-1 activation may upregulate FN mRNA and protein expression via MAPKdependent NF- $\kappa \mathrm{B}$ and AP-1 activation. Identification of such pathogenetic mechanism leading to glucose-induced increased ECM protein synthesis is of importance as these may form the basis of new drug targets or novel adjuvant treatment modalities for diabetic complications.

\section{Acknowledgements}

This work was supported in part by grants from the Canadian Diabetes Association, in honour of Glenn W Leibrock, Canadian Institutes of Health Research, and Internal Research Fund of the Lawson Health Research Institute.

\section{References}

1 Khan ZA, Chakrabarti S. Endothelins in chronic diabetic complications. Can J Physiol Pharmacol 2003;81:622-634.

2 Chakrabarti S, Khan ZA, Cukiernik M, et al. Alteration of endothelins: a common pathogenetic mechanism in chronic diabetic complications. Int J Exp Diabetes Res 2002;3:217-231. 
3 Ljubimov AV, Burgeson RE, Butkowski RJ, et al. Basement membrane abnormalities in human eyes with diabetic retinopathy. J Histochem Cytochem 1996;44:1469-1479.

4 Evans T, Deng DX, Chen S, et al. Endothelin receptor blockade prevents augmented extracellular matrix protein component mRNA expression and capillary basement membrane thickening in the retina of diabetic and galactose fed rats. Diabetes 2000;49: 662-666.

5 Roy S, Cagliero E, Lorenzi M. Fibronectin overexpression in retinal microvessels of patients with diabetes. Invest Ophthalmol Vis Sci 1996;37:258-266.

6 Chen S, Mukherjee S, Chakraborty C, et al. High glucose-induced endothelin-1 dependent fibronectin synthesis is mediated via $\mathrm{NF}-\kappa \mathrm{B}$ and $\mathrm{AP}-1$. Am J Physiol Cell Physiol 2003;284:C263-C272.

7 Yamada KM. Cell surface interactions with extracellular materials. Annu Rev Biochem 1983;52:761-799.

8 Isono M, Cruz MC, Chen S, et al. Extracellular signalregulated kinase mediates stimulation of TGF-beta1 and matrix by high glucose in mesangial cells. J Am Soc Nephrol 2000;11:2222-2230.

9 Tomlinson DR. Mitogen-activated protein kinases as glucose transducers for diabetic complications. Diabetologia 1999;42:1271-1281.

10 Pearson G, Robinson F, Beers Gibson T, et al. Mitogenactivated protein (MAP) kinase pathways: regulation and physiological functions. Endocr Rev 2001;22: 153-183.

11 Andrew EA, Stewart AS, Assoian KR, et al. Integrinmediated adhesion regulates ERK nuclear translocation and phosphorylation of Elk-1. J Cell Biol 2001; 153:273-282.

12 Haneda M, Kikkawa R, Sugimoto T, et al. Abnormalities in protein kinase $\mathrm{C}$ and MAP kinase cascade in mesangial cells cultured under high glucose conditions. J Diabetes Complic 1995;9:246-248.

13 Hua H, Goldberg HJ, Fantus IG, et al. High glucoseenhanced mesangial cell extracellular signal-regulated protein kinase activation and alpha1(IV) collagen expression in response to endothelin-1: role of specific protein kinase C isozymes. Diabetes 2001;50: 2376-2383.

14 Kyaw M, Yoshizumi M, Tsuchiya K, et al. Antioxidants inhibit endothelin-1 (1-31)-induced proliferation of vascular smooth muscle cells via the inhibition of mitogen-activated protein (MAP) kinase and activator protein-1 (AP-1). Biochem Pharmacol 2002;64: 1521-1531.

15 Chen S, Evans T, Deng D, et al. Hyperhexosemia induced functional and structural changes in the kidneys: role of endothelins. Nephron 2002;90:86-94.

16 Bozinovski S, Jones JE, Vlahos R, et al. Granulocyte/ macrophage-colony-stimulating factor (GM-CSF) regulates lung innate immunity to lipopolysaccharide through Akt/ERK activation of NF kappa B and AP-1 in vivo. J Biol Chem 2002;277:42808-42814.

17 Wick W, Stock J, Seyfried J, et al. CD95/CD95 ligandindependent potentiation of treosulfan cytotoxicity by $\mathrm{BSO}$ in malignant glioma cells in vitro and in vivo. Int $\mathrm{J}$ Oncol 2002;21:213-220.

18 Chen S, Khan ZA, Cukiernik M, et al. Differential activation of NF- $\kappa \mathrm{B}$ and $\mathrm{AP}-1$ in increased fibronectin synthesis in target organs of diabetic complications. Am J Physiol Endocrinol Metab 2003;284:E1089E1097.
19 Schmittgen TD, Zakrajsek BA. Effect of experimental treatment on housekeeping gene expression: validation by real-time, quantitative RT-PCR. J Biochem Biophys Methods 2000;46:69-81.

20 Chen S, Evans T, Mukherjee K, et al. Diabetes-induced myocardial structural changes: role of endothelin-1 and its receptors. J Mol Cell Cardiol 2000;32: 1621-1629.

21 Haneda M, Araki S, Togawa M, et al. Mitogen-activated protein kinase cascade is activated in glomeruli of diabetic rats and glomerular mesangial cells cultured under high glucose conditions. Diabetes 1997;46:847-853.

22 Haneda M, Kikkawa R, Sugimoto T, et al. Abnormalities in protein kinase $\mathrm{C}$ and MAP kinase cascade in mesangial cells cultured under high glucose conditions. J Diabetes Complic 1995;9:246-248.

23 Brownlee M. Biochemistry and molecular cell biology of diabetic complications. Nature 2001;414:813-820.

24 King GL, Brownlee M. The cellular and molecular mechanisms of diabetic complications. Endocrinol Metab Clin North Am 1996;25:255-270.

25 Chen S, Apostolova MD, Cherian MG, et al. Interaction of endothelin-1 with vasoactive factors in mediating glucose-induced increased permeability in endothelial cells. Lab Invest 2000;80:1311-1321.

26 Levin ER. Endothelins. N Engl J Med 1995;333: 356-363.

27 Quehenberger P, Bierhaus A, Fasching P, et al. Endothelin 1 transcription is controlled by nuclear factor-kappaB in AGE-stimulated cultured endothelial cells. Diabetes 2000;49:1561-1570.

28 Chakraborty C, Barbin YP, Chakrabarti S, et al. Endothelin-1 promotes migration and induces elevation of $[\mathrm{Ca}(2+)](\mathrm{i})$ and phosphorylation of MAP kinase of a human extravillous trophoblast cell line. Mol Cell Endocrinol 2003;28:63-73.

29 Cheng CM, Hong HJ, Liu JC, et al. Crucial role of extracellular signal-regulated kinase pathway in reactive oxygen species-mediated endothelin-1 gene expression induced by endothelin-1 in rat cardiac fibroblasts. Mol Pharmacol 2003;63:1002-1011.

30 Kwon S, Lee WJ, Fang LH, et al. Mitogen-activated protein kinases partially regulate endothelin-1-induced contractions through a myosin light chain phosphorylation-independent pathway. J Vet Med Sci 2003;65:225-230.

31 Tamura K, Chen YE, Lopez LM, et al. Molecular mechanism of fibronectin gene activation by cyclic stretch in vascular smooth muscle cells. J Biol Chem 2000;275:34619-34627.

32 Moriguchi Y, Matsubara H, Mori Y, et al. Angiotensin II-induced transactivation of epidermal growth factor receptor regulates fibronectin and transforming growth factor-beta synthesis via transcriptional and posttranscriptional mechanisms. Circ Res 1999;84:1073-1084.

33 Tamura K, Nyui N, Tamura N, et al. Mechanism of angiotensin II-mediated regulation of fibronectin gene in rat vascular smooth muscle cells. J Biol Chem 1998;273:26487-26496.

34 Lee BH, Kim MS, Rhew JH, et al. Transcriptional regulation of fibronectin gene by phorbol myristate acetate in hepatoma cells: a negative role for NF-kappa B. J Cell Biochem 2000;76:437-451.

35 Morigi M, Angioletti S, Imberti B, et al. Leukocyteendothelial interaction is augmented by high glucose concentrations and hyperglycemia in a NF- $\kappa \mathrm{B}$-dependent fashion. J Clin Invest 1998;101:1905-1915. 